\title{
Prevalence of Underweight, Stunting and Thinness Among Adolescent Girls in Kavre District
}

\author{
Mansur $\mathrm{DI}^{1}$, Haque $\mathrm{MK}^{2}$, Sharma $\mathrm{K}^{3}$, Mehta $\mathrm{DK}^{4}$, Shakya $\mathrm{R}^{5}$
}

\begin{abstract}
Introduction: Poor nutritional status during adolescence is an important determinant of health outcome. The adolescents have different needs and have diverse problems. Nutritional assessments among adolescents are important as they are the future parents and constitute a potentially susceptible group. The present study is an attempt to evaluate the prevalence of underweight, stunting and thinness including overweight among adolescent girls from rural community. Material and Methods: A cross-sectional study was conducted among school going adolescent girls, 9-16 years studying in various schools in rural area of Kavre district, Nepal during $15^{\text {th }}$ March to $15^{\text {th }}$ September 2014. The weight and height were recorded from each participant in kilogram and centimetre respectively, and nutritional status of the adolescent girls was assessed through the Z-scores of underweight (weight for age), stunting (height for age) and thinness (BMI for age) according to WHO criteria. Data was entered and analyzed by using SPSS 19.0. Results: The overall prevalence of underweight, stunting and thinness was $31.98 \%, 21.08 \%$ and $14.94 \%$ respectively. It was concluded that highest (49.5\%) prevalence of underweight was among 11 years of adolescent girls and the lowest $(20.7 \%)$ was found in the age group of 13 years. Stunting was highest in age group of 9 years (37.34\%) and the lowest prevalence of stunting was $10.7 \%$ in the age group of 14 years. The highest prevalence $(24.2 \%)$ of thinness was found in 9 years and lowest prevalence (11.0\%) was found in 10 years adolescent girls. Conclusion: It is concluded that there is a high prevalence of under nutrition among studied adolescent girls in the rural areas of Kavre district. Health education and nutrition interventions are needed on priority basis.
\end{abstract}

Key words: Adolescent girls, anthropometry, stunting, thinness, underweight

\section{Introduction}

A dolescent is the developmental period between childhood and adulthood. The World health organization defines adolescents as young people between the ages of 9-19 years ${ }^{1}$. Out of estimated 27 million population ${ }^{2}$ in Nepal around 23 percent are adolescents who form a crucial segment of the society ${ }^{3}$. Their current nutritional
'Dr. Dil Islam Mansur, MBBS, MS, Assistant Professor, ${ }^{2}$ Dr. Mohammad Khurshidul Haque, MBBS, MS, Associate Professor and Head, ${ }^{3} \mathrm{Mrs}$. Kalpana Sharma, MSc, Lecturer, ${ }^{4} \mathrm{Mr}$. Dilip Kumar Mehta, MSc, Lecturer, ${ }^{5}$ Ms. Rojina Shakya, MSc, Lecturer. All from the Department of Anatomy, Kathmandu University School of Medical Sciences, Dhulikhel, Nepal

\author{
Address for correspondence: \\ Dr. Dil Islam Mansur \\ Assistant Professor, Department of Anatomy \\ Kathmandu University, \\ School of Medical Sciences (KUSMS) \\ Dhulikhel, Nepal \\ E-mail: dillslam@kusms.edu.np \\ Tel: 00977-9849678367
}

\section{How to cite}

Mansur DI, Haque MK, Sharma K, Mehta DK, Shakya R. Prevalence of Underweight, Stunting and Thinness Among Adolescent Girls in Kavre District. J Nepal Paediatr Soc 2015;35(2):129-135.

doi: http://dx.doi.org/10.3126/jnps.v35i2.12794

This work is licensed under a Creative Commons Attribution 3.0 License.

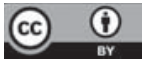

status will decide the well-being of the present as well as the future generations. Adolescence is the second most critical period of physical growth after the period of infancy ${ }^{4,5}$. It is a time of enormous physiological, cognitive and psychosocial changes, largely dependent on hormonal and environmental influences ${ }^{4,6}$. 
The girl child is considered to be a burden and discrimination against her is rampant in all strata of society irrespective of class and economic conditions. It is generally observed that girls and women particularly in rural households suffer relative negligence with reference to nutritional inputs ${ }^{7}$.

Anthropometric measurements remain the most practically useful means for the assessment of the nutritional status of a population ${ }^{8}$. Generally, nutritional status is assessed by low weight for age (underweight), low height for age (stunting) and low BMI for age (thinness) following different internationally and regionally recommended standards ${ }^{9}$.

Studies on the assessment of nutritional status of adolescents are less in number and a national database has not yet been developed. Hence, the present study was conducted to determine the prevalence of underweight, stunning and thinness among the adolescent girls using the recommended anthropometric indicators which allow the determination of the nature and extent of under nutrition in the rural community in Kavre district of Nepal.

\section{Material and Methods}

A cross sectional descriptive study was conducted among adolescent girls attending five different government schools in rural community of Kavre district, Nepal. A total number of sample sizes were 716 school going adolescent girls randomly selected within the age group of 9-16 years. The study was conducted during the period from $15^{\text {th }}$ March to $15^{\text {th }}$ September 2014. After taking permission from the school authority, the class teachers of class were explained the purpose of the study and rapport was built up with the girl students and verbal consent was obtained from them. The students who were physically challenged were excluded from the study.

Data was obtained from each interested participant. Height was recorded from heel (bare feet) to highest point of vertex in normal anatomical position by using measuring tape in centimetre and weight was measured using a standing weighing machine in kilogram. Body Mass Index (BMI) was derived by using the standard equation: $\mathrm{BMI}=$ weight $(\mathrm{kg}) /$ height $\left(\mathrm{m}^{2}\right)$.

WHO anthropometric classification was used for the assessment of under nutrition. WHO has classified the children using three categories: 'underweight' is defined as low weight for age and it reflects present (acute) and past (chronic) under nutrition: children with Z-scores $<-2.00$ are said to be underweight, 'stunting' is defined as a low height for age for children, and it measures the past (chronic) child under nutrition: children with Z-scores $<-2.00$ are said to be stunted and 'thinness' is defined as low BMI for age for children, and it is a measure of current or acute under nutrition: children with Z-scores $<-2.00$ are said to be thinned whereas children with Z-scores $>2$ are said to be overweight. Adolescent girls were considered as having underweight, stunting and thinness if their weight for age, height for age and BMI for age Z-scores were below -2.0 SD of the WHO reference ${ }^{9}$. Data was entered in MS Excel 2010 and analyzed by using SPSS 19.0 .

The present study was approved by the Institutional Review Committee prior to start the study (Ref. No. 53/14).

\section{Results}

The subjects for this study were 716 adolescent girls. Age wise distribution of subjects, descriptive statistics (mean $\pm \mathrm{SD}$ ) of height, weight and BMI among adolescent girls is mentioned in Table 1 . The overall mean \pm SD of height, weight and $\mathrm{BMI}$ were 143.24 $\pm 6.33 \mathrm{~cm}, 37.38 \pm 11.66 \mathrm{~kg}$ and $18.04 \pm 3.40 \mathrm{~kg} / \mathrm{m} 2$ respectively. The age specific mean height, weight and BMI were increased with age with an exception, observed in 16 years (in height).

As shown in table 2; it has been concluded that the overall prevalence of underweight (low weight for age) was $31.98 \%$ with reference to WHO values. The adolescents with the age of 11 years had high percentage of underweight $(49.5 \%)$ and the lowest $(20.7 \%)$ was found in the age of 13 years.

The prevalence of stunting (low height for age) was shown in Table 3. The overall prevalence of stunting was $21.08 \%$ as compared to WHO values which was highest among the age group of 9 years (37.34\%). The lowest prevalence of stunting was $10.7 \%$ among the age group of 14 years of adolescent.

Similarly, $14.94 \%$ of the adolescent girls were found to be thin (low BMI for age) as described by WHO criteria. The highest (24.2\%) prevalence of thinness was found among nine years and the lowest (11.0\%) prevalence was found among 10 years adolescent girls. The highest prevalence of overweight was $4.6 \%$ in the age group of 13 years and was absent in the adolescent girls of 14 years. 
Table 1: Mean, SD, Minimum and Maximum of Height, Weight and BMI according to age

\begin{tabular}{|c|c|c|c|c|c|c|c|}
\hline Age(years) & $n$ & $\%$ & Parameters & Mean & SD & Minimum & Maximum \\
\hline \multirow{3}{*}{9} & \multirow{3}{*}{99} & \multirow{3}{*}{13.82} & Height (cm) & 125.39 & 7.56 & 111 & 142 \\
\hline & & & Weight(kg) & 23.62 & 4.96 & 18 & 51 \\
\hline & & & $\mathrm{BMI}\left(\mathrm{kg} / \mathrm{m}^{2}\right)$ & 15.03 & 2.80 & 10.56 & 31.27 \\
\hline \multirow{3}{*}{10} & \multirow{3}{*}{82} & \multirow{3}{*}{11.46} & Height (cm) & 131.76 & 7.72 & 117 & 149 \\
\hline & & & Weight(kg) & 27.99 & 5.86 & 21 & 60 \\
\hline & & & $\mathrm{BMI}\left(\mathrm{kg} / \mathrm{m}^{2}\right)$ & 16.11 & 2.82 & 11.06 & 29.55 \\
\hline \multirow{3}{*}{11} & \multirow{3}{*}{105} & \multirow{3}{*}{14.66} & Height (cm) & 136.48 & 7.14 & 122 & 155 \\
\hline & & & Weight(kg) & 30.48 & 5.87 & 21 & 50 \\
\hline & & & $\mathrm{BMI}\left(\mathrm{kg} / \mathrm{m}^{2}\right)$ & 16.34 & 2.72 & 11.19 & 26.57 \\
\hline \multirow{3}{*}{12} & \multirow{3}{*}{80} & \multirow{3}{*}{11.17} & Height (cm) & 142.34 & 6.12 & 124 & 156 \\
\hline & & & Weight(kg) & 37.12 & 9.29 & 20 & 70 \\
\hline & & & $\mathrm{BMI}\left(\mathrm{kg} / \mathrm{m}^{2}\right)$ & 18.24 & 4.05 & 11.81 & 30.90 \\
\hline \multirow{3}{*}{13} & \multirow{3}{*}{87} & \multirow{3}{*}{12.16} & Height (cm) & 149.95 & 6.58 & 133 & 169 \\
\hline & & & Weight(kg) & 42.10 & 8.07 & 26 & 58 \\
\hline & & & $\mathrm{BMI}\left(\mathrm{kg} / \mathrm{m}^{2}\right)$ & 18.76 & 3.70 & 11.53 & 28.15 \\
\hline \multirow{3}{*}{14} & \multirow{3}{*}{84} & \multirow{3}{*}{11.73} & Height (cm) & 152.26 & 4.85 & 135 & 159 \\
\hline & & & Weight(kg) & 43.07 & 7.89 & 25 & 58 \\
\hline & & & $\mathrm{BMI}\left(\mathrm{kg} / \mathrm{m}^{2}\right)$ & 18.58 & 3.40 & 9.95 & 25.33 \\
\hline \multirow{3}{*}{15} & \multirow{3}{*}{105} & \multirow{3}{*}{14.66} & Height (cm) & 154.41 & 4.87 & 145 & 165 \\
\hline & & & Weight(kg) & 47.43 & 8.15 & 31 & 67 \\
\hline & & & $\mathrm{BMI}\left(\mathrm{kg} / \mathrm{m}^{2}\right)$ & 19.94 & 3.61 & 12.42 & 29 \\
\hline \multirow{3}{*}{16} & \multirow{3}{*}{74} & \multirow{3}{*}{10.34} & Height (cm) & 153.39 & 5.84 & 116 & 165 \\
\hline & & & Weight(kg) & 50 & 8.92 & 27 & 88 \\
\hline & & & $\mathrm{BMI}\left(\mathrm{kg} / \mathrm{m}^{2}\right)$ & 21.33 & 4.15 & 11.92 & 37.97 \\
\hline \multirow{3}{*}{ Overall } & \multirow{3}{*}{716} & \multirow{3}{*}{100} & Height (cm) & 143.24 & 6.33 & 111 & 169 \\
\hline & & & Weight (kg) & 37.38 & 11.66 & 18 & 88 \\
\hline & & & BMI $\left(\mathrm{kg} / \mathrm{m}^{2}\right)$ & 18.04 & 3.40 & 15.03 & 21.33 \\
\hline
\end{tabular}

Table 2: Prevalence of underweight (weight for age) among the adolescent girls

\begin{tabular}{|c|c|c|c|c|c|}
\hline \multirow{2}{*}{ Age (years) } & \multicolumn{2}{|c|}{ Underweight (<-2 Z-score) } & \multicolumn{2}{|c|}{ Normal ( $\mathbf{- 2}$ Z-score) } & \multirow{2}{*}{ Total (n) } \\
\cline { 2 - 5 } & $\mathbf{n}$ & $\mathbf{\%}$ & $\mathbf{n}$ & $\mathbf{\%}$ & 105 \\
\hline 9 & 35 & 33.33 & 70 & 66.67 & 80 \\
\hline 10 & 27 & 33.75 & 53 & 66.25 & 99 \\
\hline 11 & 49 & 49.49 & 50 & 50.51 & 82 \\
\hline 12 & 31 & 37.80 & 51 & 62.20 & 87 \\
\hline 13 & 18 & 20.69 & 69 & 79.31 & 84 \\
\hline 14 & 22 & 26.19 & 62 & 73.81 & 105 \\
\hline 15 & 29 & 27.62 & 76 & 72.38 & 74 \\
\hline 16 & 18 & 24.32 & 56 & 75.68 & 716 \\
\hline
\end{tabular}


Table 3: Prevalence of stunting (height for age) among the adolescent girls

\begin{tabular}{|c|c|c|c|c|c|}
\hline \multirow{2}{*}{ Age (years) } & \multicolumn{2}{|c|}{ Stunting (<-2 Z-score) } & \multicolumn{2}{c|}{ Normal ( $\mathbf{- 2}$ Z-score) } & \multirow{2}{*}{ Total (n) } \\
\cline { 2 - 5 } & $\mathbf{n}$ & $\mathbf{\%}$ & $\mathbf{n}$ & $\mathbf{\%}$ & 99 \\
\hline 9 & 37 & 37.37 & 62 & 62.63 & 82 \\
\hline 10 & 23 & 28.05 & 59 & 71.95 & 105 \\
\hline 11 & 28 & 26.67 & 77 & 73.33 & 80 \\
\hline 12 & 17 & 21.25 & 63 & 83.91 & 87 \\
\hline 13 & 14 & 16.09 & 73 & 89.29 & 84 \\
\hline 14 & 9 & 10.71 & 75 & 88.57 & 105 \\
\hline 15 & 12 & 11.43 & 93 & 85.14 & 74 \\
\hline 16 & 11 & 14.86 & 63 & $\mathbf{7 8 . 9 2}$ & $\mathbf{7 1 6}$ \\
\hline
\end{tabular}

Table 4: Prevalence of thinness (BMI for age) among the adolescent girls

\begin{tabular}{|c|c|c|c|c|c|c|c|}
\hline \multirow{2}{*}{ Age (years) } & \multicolumn{2}{|c|}{ Thinness ( $\leq-2$ Z-score) } & \multicolumn{2}{|c|}{ Normal (-2 to 2 Z-score) } & \multicolumn{2}{|c|}{ Overweight (> 2 Z-score) } & \multirow{2}{*}{$\begin{array}{c}\text { Total } \\
\text { (n) }\end{array}$} \\
\hline & $\mathbf{n}$ & $\%$ & $\mathbf{n}$ & $\%$ & n & $\%$ & \\
\hline 9 & 24 & 24.24 & 72 & 72.73 & 3 & 3.03 & 99 \\
\hline 10 & 9 & 10.97 & 71 & 86.59 & 2 & 2.44 & 82 \\
\hline 11 & 14 & 13.33 & 89 & 84.76 & 2 & 1.90 & 105 \\
\hline 12 & 15 & 18.75 & 57 & 71.25 & 8 & 10 & 80 \\
\hline 13 & 12 & 13.79 & 71 & 81.61 & 4 & 4.60 & 87 \\
\hline 14 & 15 & 17.86 & 69 & 82.14 & - & - & 84 \\
\hline 15 & 12 & 11.43 & 92 & 87.62 & 1 & 0.95 & 105 \\
\hline 16 & 6 & 8.11 & 65 & 87.84 & 3 & 4.05 & 74 \\
\hline Overall & 107 & 14.94 & 586 & 81.84 & 23 & 3.22 & 716 \\
\hline
\end{tabular}

\section{Discussion}

Most countries in Asia have high or very high prevalence of underweight, stunting and thinness, the prevalence being far higher in Southern Asia. Southeastern Asia ranks second in the descending order of prevalence of underweight and third for stunting and thinness ${ }^{10}$. The present study highlights the extent of nutritional status in terms of underweight, stunting, thinness and overweight among adolescent girls of rural community of Kavre district. Nutritional status was evaluated using anthropometric indicators recommended by the WHO expert committee. Assessing the nutritional status of groups of children is an essential part of monitoring the health of a community ${ }^{11}$. The use of appropriate anthropometric indicators allows determination of the nature and extent of nutritional status in the rural community.

It has been found that under-nutrition during adolescence is a major health problem in most of the districts of Nepal including Kavre district. Many studies reported high prevalence of underweight in different regions of the world especially in Asian countries. A study reported very high percentage of prevalence of underweight $51.7 \%$ among adolescents in Wardha,
Maharashtra, India ${ }^{12}$. Ghosh et al. observed the overall underweight level was 46.09\% among girls of aged 6-10 years in Kathmandu valley ${ }^{13}$. The high rate of underweight (41.33\%) was reported among rural adolescent girls from Khagrachhari district in Chittagong hill region of Bangladesh ${ }^{14}$. In other context, low prevalence of underweight has also been reported $16.5 \%$ and $16.9 \%$ of girls with age group of $5-15$ years in Mugu and Humla districts of far western region in Nepal ${ }^{15}$.

It is also apparent from the study that the overall prevalence of stunting was $21.08 \%$ among studied subjects which was almost similar as compared with the finding (23.28\%) reported in Bareilly district, (UP), India by Singh et al. with use of WHO reference ${ }^{16}$. However, use of Indian reference data, Maiti et al. found $18.10 \%$ of stunting among early adolescent school girls of Paschim Medinipur district, West Bengal, India ${ }^{17}$ and Anand et al. reported $20 \%$ prevalence of stunting at rural North India ${ }^{18}$ which was consistent with the present result. In contrast to this, many studies reported high prevalence of stunting among rural adolescent girls. The extent of stunting was higher (50.3\%) at rural area of Darjeeling district of West Bengal using WHO reference value ${ }^{19}$. 
Bose et al. reported the frequency of stunting to be $48.4 \%$ among pre-adolescent school girls ${ }^{20}$. Ghosh et al. reported high prevalence of stunting (43.42\%) among school going girls with age group of 6-10 years on Kathmandu valley, Nepal ${ }^{13}$. Maiti et al. also noticed the prevalence of stunting as $34.20 \%$ among rural early adolescent school girls based on WHO reference data ${ }^{17}$. In Bangladesh, a study conducted by Alam et al. found that the prevalence of stunting was $32 \%$ of adolescent girls in rural areas ${ }^{21}$. In other context, low prevalence of stunted has also been reported 9.2\% and $7.7 \%$ of girls with age group of 5-15 years in Humla and Mugu districts of far western region in Nepal ${ }^{15}$. The basic reason behind stunting indicates the long term cumulative inadequacies of health and nutrition and an insufficient intake of nutrients during the early stage of childhood ${ }^{9}$.

It is also apparent from the present study it was confirmed that the overall prevalence of thinness and overweight was $14.94 \%$ and $3.22 \%$ among studied subjects. The thinness was found to be more common among nine years and overweight among 13 years. A noteworthy point is that both thinness and overweight were coexisting among the girls in studied area. A similar finding $(14.7 \%)$ also reported by Das et al. among adolescent girls in a rural area of North 24 Parganas district, West Bengal. India ${ }^{22}$.

In contrast, there was high prevalence of thinness reported in many studies in various regions of world. A community based cross sectional study was carried out among adolescent girls (10-19 years) in selected villages of the Kolar district, Karnataka, India and reported the prevalence of thinness as $73.5 \%$ as per Indian standards ${ }^{23}$. Choudhary et al. have reported $68.52 \%$ of adolescents having a BMI less than $18.5 \mathrm{~kg} /$ meter square in rural area of Varanasi ${ }^{24}$ and studies overseas in developing country like Bangladesh have also reported higher rate of prevalence (67\%) of thinness among girls in the south east region ${ }^{25}$. Thapa et al. noticed $21.13 \%$ girl child of Humla and $20.12 \%$ girl child of Mugu in the age group between 5 and 15 years were found to be thin ${ }^{15}$. This higher figure of thinness in their study may be attributed to poor socioeconomic conditions of mountain regions. The poor nutritional status of adolescent girls has important implications in terms of physical work capacity and adverse reproductive outcomes.

However, low prevalence of thinness was also reported in the different studies. Sood et al. reported a prevalence of thinness $5.1 \%$ adolescent girls in Bangalore City, Karnataka, India ${ }^{26}$. In another study done by Mushtaq et al. in Lahore, Pakistan, $10 \%$ children aged 5-12 years were found to be thin ${ }^{27}$. Sachan et al. also reported low prevalence of thinness (11.4\%) among adolescent girls ${ }^{28}$. The prevalence of thinness was significantly higher in the early age groups in most of the cases, but decreased with age. A similar trend has been reported by Sahabuddin et al. who opined that the prevalence of thinness decreased with age ${ }^{25}$.

In the present study, it was also observed that the overall overweight among adolescents was $3.22 \%$ which was same as compared to the data (3.6\%) reported by Patanwar et al. among Kurmi adolescent girls from Raipur city, Chhattisgarh, India ${ }^{29}$. A similar finding (3.9\%) also reported by Sachan et al. from Lucknow, UP, India ${ }^{28}$. Low prevalence of overweight were also reported among rural adolescents from Assam $(0.3 \%)^{30}$ and rural Wardha $(2.0 \%)^{31}$. While Subramanyam et al. ${ }^{32}$ and Mehta et al. ${ }^{33}$ in their study, reported a prevalence of overweight was $9.6 \%$ and $15.2 \%$ respectively, which was higher than the present result and could be incriminated to the affluent society.

The present study and other previous study has focused that under nutrition in terms of underweight, stunting and thinness among adolescent girls is a major health problem at rural areas of Nepal. It is also mentioned that under nutrition is an indicator of acute or chronic nutrition deprivation ${ }^{9}$. Further studies on larger sample are required to determine the most appropriate reference to measure the nutritional status among adolescents. Hence, the special emphases are needed to formulate various developmental and healthcare programs for rural communities to prevent under nutrition; and also need health education to improve the health and nutritional status. There is an urgent need to intensify efforts to improve the nutritional profile of children to optimize human resource development.

\section{Conclusion}

The present study concludes the high rate of prevalence of underweight; stunting and thinness but low prevalence of overweight among adolescent girls in rural community of Kavre district and these reflect major health problems among them.

Acknowledgements: The authors would like to acknowledge the Principals of all schools providing permission to carry out the study. The authors are also acknowledged with deep gratitude for the cooperation and endurance of the students who participated in this study. The authors also thank to Mr. Binod Timalsina for his contribution during the data interpretation of this study. 
Funding: None

Conflict of Interest: Nil

Permission from IRB: Yes

\section{References}

1. World Health Organization/UNICEF: A picture of health: a review of annotated bibliography of the health of young people in developing countries. WHO/FHE/ADH 195.14. WHO, Geneva; 1995:13.

2. WHO. Country Health Indicators. www. who.int/ whosis/ country/indicators.cfm? npl (accessed on 11/9/07)

3. Central Bureau of Statistics. Population Census 2001 National Report. HMG/Nepal National Planning Commission Secretariat Central Bureau of Statistics in collaboration with UNFPA Nepal, Kathmandu 2002.

4. Heald FP, Gong EJ: Diet, nutrition and adolescence. In Modern nutrition in health and disease. Ninth edition. Edited by Shils ME, Ross AC. Williams and Wilkins, Maryland, USA; 1999.

5. Rees JM, Nuumark-Sztainer D, Kohn M, Jocobson M. Improving the nutritional health of adolescents - position statement - society for adolescent medicine. J Adolesc Health 1999;24:461-462.

6. Nwokocha ARC: Adolescence and associated problems. In paediatrics and child health in a tropical region. Edited by Azubuike JC, Nkanginieme KEO. Nigeria African educational services, Services, P.O Box 1691, 2 Dengramite Avenue, Owerri, Nigeria; 1999:97-109.

7. Devadas RP, Malathan G. A women's first decade. Paper presented at the conference on women's NGO constitution, for equality, development and peace, New Delhi, 1985: 69-72.

8. Laditan AAO, Johnson AOK. Nutrition and nutritional assessment in childhood. In: Azubuike JC, Nkanginieme KEO (eds). Paediatrics and child health in a tropical region. Owerri: African educational services. 1999:162-165.

9. WHO. Physical status: the use and interpretation of anthropometry: Technical report series Geneva; World Health Organization; 1995. Report No.:854.

10. Onis M, Monteiro C, AkreJ, Clugston G. The worldwide magnitude of protein-energy malnutrition: an overview from the WHO global database on child growth. Bull WHO 1993;71(5):703-12.

11. Rabasa Al, Omatara BA, Padomu MKO. Assessment of nutritional status of children in a Sub-Saharan rural community with reference to anthropometry. Sahel Med J 1998;1:15-8.

12. Dambhare DG, Bharambe MS, Mehendale AM, Garg BS. Nutritional status and morbidity among school going adolescents in Wardha, a Peri-Urban area. Online J Health Allied Scs 2010;9(2):3

13. Ghosh A, Adhikari P, Chowdhury SD, Ghosh T. Prevalence of undernutrition in Nepalese children. Ann Hum Biol 2009; 36(1):38-45.

14. Hossain GMM, Sarwar MT, Rahman MH, Rouf SMA, Raza S, Daula AD, Hossain S. A study on nutritional status of the adolescent girls at Khagrachhari district in Chittagong hill tracts, Bangladesh. Am J of Life Sci 2013; 1(6):278-282.

15. Thapa M, Neopane AK, Singh UK, Aryal N, Agrawal $\mathrm{K}$, Shrestha B. Nutritional status of children in two districts of the mountain region of Nepal. J Nepal Health Res Counc 2013;11(25):235-39.

16. Singh JP, Kariwal $P$, Gupta SB, Singh AK, Imtiaz D. Nutritional status and morbidity among school going children: A scenario from a rural India. Sch J App Med Sci 2014; 2(1D):379-383.

17. Maiti S, De D, Chatterjee K, Jana K, Ghosh D, Paul S. Prevalence of stunting and thinness among early adolescent school girls of Paschim Medinipur district, West Bengal. Int J Biol Med Res 2011; 2(3): 781-783.

18. Anand K, Kant S, Kapoor SK. Nutritional status of adolescent school children in rural north India. Indian J Pediatr 1999; 36: 810-815.

19. Dey I, Biswas R, Ray K, Bhattacherjee S, Chakraborty $M$, Pal PP. Nutritional status of school going adolescents in a rural block of Darjeeling, West Bengal, India. The Health 2011; 2(3):75-77.

20. Bose K, Bisai S, Chakraborty J, Datta N, Banerjee P. Extreme levels of underweight and stunting among pre-adolescent children of low socioeconomic class from Madhyamgram and Barasat, West Bengal, India. Coll Antropol 2008; 32(1): 73-77.

21. Alam N, Roy SK, Ahmed T, Ahmed AMS. Nutritional status, dietary intake, and relevant knowledge of adolescent girls in rural Bangladesh. $J$ Health Popul Nutr 2010; 28(1):86-94.

22. Das NK, Paul S. Pervasiveness of thinness among early adolescent rural girls in Bankura district of West Bengal, India. Int J Modern Biol Med 2012; 2(1):32-38.

23. Shivaramakrishna HR, Deepa AV, Sarithareddy M. Nutritional status of adolescent girls in rural area of Kolar district - A cross-sectional study. Al Ameen J Med Sci 2011; 4(3):243-246. 
24. Choudhary S, Mishra CP, Shukla KP. Nutritional status of adolescent girls in rural area of Varanashi. Indian J Prev Soc Med 2003;34(1):53-61.

25. Shahabuddin AK, Talukdar K, Talukdar MK, Hassan M, Seal A, Rahman Q, Mannan A, Tomkins A, Costello A. Adolescent nutrition in a rural community in Bangladesh. Indian J Pediatr 2000; 67(2):93-98.

26. Sood A, Sundararaj P, Sharma S, Kurpad AV, Muthayya S. BMI and body Fat percent: Affluent adolescent girls in Bangalore City. Indian J Pediatr 2007;44:587-91.

27. Mushtaq MU, Gull S, Khurshid U, Shahid U, Shad MA, Siddiqui AM. Prevalence and sociodemographic correlates of stunting and thinness among Pakistani primary school children. BMC Public Health 2011;11:790.

28. Sachan $B$, Idris $M Z$, Jain $S$, Kumari $R$, Singh $A$. Nutritional status of school going adolescent girls in Lucknow district. J Med Nutr Nutraceut 2012;1:101-5.
29. Patanwar P, Sharma KKN. Nutritional status of Kurmi adolescent girls of Raichur city of Chhatishgarh, India. International Journal of Scientific and Research Publications 2013;3(11):16.

30. Medhi GK, Hazarika NC, Mahanta J. Nutritional status of adolescents among tea garden workers. Indian J Pediatr 2007;74:343-47.

31. Deshmukh PR, Gupta SS, Bharambe MS, Dongre AR, Maliye C, Kaur S. Nutritional status of adolescents in rural Wardha. Indian J Pediatr 2006;73:139-41.

32. Subramanyam V, Jayashree R, Rafi M. Prevalence of overweight and obesity in affluent adolescent girls in Chennai in 1981 and 1998. Indian Pediatr 2003;40:332-36.

33. Mehta M, Bhasin SK, Agrawal K, Dwivedi S. Obesity amongst affluent adolescent girls. Indian J Pediatr 2007;74:619-22. 